\title{
Influence of Spatial Variation in Subgrade Properties on the Design of Highway Flexible Pavements
}

\author{
Nwakaire Chidozie Madu ${ }^{1, ~}$, Chukwu Chinagorom Joshua ${ }^{1}$, Udemba Jonathan Nwachukwu ${ }^{2}$ \\ ${ }^{1}$ Department of Civil Engineering, Nnamdi Azikiwe University, Awka, Nigeria \\ ${ }^{2}$ National Inland Waterways Authority, Warri, Nigeria
}

Email address:

cm.nwakaire@unizik.edu.ng (N. C. Madu)

*Corresponding author

\section{To cite this article:}

Nwakaire Chidozie Madu, Chukwu Chinagorom Joshua, Udemba Jonathan Nwachukwu. Influence of Spatial Variation in Subgrade Properties on the Design of Highway Flexible Pavements. American Journal of Applied Scientific Research. Vol. 2, No. 6, 2016 , pp. 65-74. doi: 10.11648/j.ajasr.20160206.16

Received: October 1, 2016; Accepted: November 18, 2016; Published: December 21, 2016

\begin{abstract}
Influence of spatial variation in subgrade properties on the integrity of highway pavement design is the burden of this research. Interruption, delay and discomfort in transportation flow that characterize roads across the globe due to poor pavement conditions are pathetic experiences. This work is an attempt to investigate the influence of subgrade variation on the design thicknesses of highway flexible pavements, using subgrade properties and traffic characteristics encountered along the Enugu-Onitsha expressway. Soil samples collected from selected sections of the expressway were subjected to geotechnical laboratory tests like particles size distribution, Atterberg's limits, compaction and California bearing ratio in order to analyse their properties. The results generated from these three samples from different stations across the road showed that the soil materials along the Enugu-Onitsha expressway vary significantly. Sample from Nkpor, Awkuzu and Kwata stations contain $15 \%, 45 \%$ and $80 \%$ fines (silt and clay) respectively, likewise their MDD and OMC are $1852 \mathrm{KN} / \mathrm{m}^{3}, 1980 \mathrm{KN} / \mathrm{m}^{3}$ and $1788 \mathrm{KN} / \mathrm{m}^{3} ; 11.7 \%, 11 \%$, and $14.6 \%$ respectively. The 48 hour soaked CBR values of soil samples from Nkpor and Awkuzu stations are $8 \%$ and $9 \%$ respectively while Kwata station is $2.3 \%$. The plasticity index and liquid limit results were also $11 \%$; $31 \%$ and $9 \% ; 27.4 \%$ for Awkuzu and Kwata samples while Nkpor sample in a non-plastic soil. Based on ASSHTO classification, the soils fall within A-2-4, A-6 and A-4 categories which depicted a significant variation in properties, fair to bad. Based on the design outputs for pavement thicknesses, it was concluded that designing a length of highway with a single CBR value will be uneconomical for areas with significantly higher surface modulus as well as providing insufficient thicknesses for areas with lower actual CBR than the observed. Sectional pavement design at not more than $1 \mathrm{~km}$ intervals was recommended.
\end{abstract}

Keywords: Pavement, Design, Subgrade, Variation, CBR, Asphalt

\section{Introduction}

Over the years, significant efforts have been made in Nigeria towards the development of highway infrastructures, but despite the efforts the undue failure of road pavements at quite an alarming rate remains characteristic of most Nigerian roads. Different stakeholders have been worried about the causes and possible remedies to this menace. Besides, it has been observed that not all the sections of the road pavements fail at the same time. Some sections of the road pavements still stand and some have outlasted their design life. From the Civil Engineer's perspective, this scenario could be as a result of one or combination of some of these; carelessness workmanship, poor supervision and quality control, inadequate drainage provisions, ignorance of regular maintenance programs, insufficient initial soil exploration, among others. Whichever be the case, the influence of bad roads on traffic flow, travelers comfort, and environmental condition of an area cannot be over emphasized. The Enugu-Onitsha Expressway within South- 
East Nigeria was chosen as a case study for this study. This major road that connects important locations between Anambra and Enugu States have recorded tremendous loss of lives and properties, human injuries, environmental pollution, traffic congestion, as well as armed robbery attacks. All these could be linked, directly or indirectly, to the deteriorated state of the highway.

Roads are very significant infrastructures that remain critical to the well-being, growth and expansion of any geographical location. Due to the high investment cost involved in their provision, they are expected to be durable and resilient, and to perform satisfactorily throughout their service lives [1]. A Flexible pavement is a structure that typically consists of layers of different materials that increase with strength towards the surface (weakest layer on the bottom, strongest layer at the surface) [2]. A flexible pavement relies on this layered system to distribute traffic loads over the sub-grade. The load carrying capacity of a flexible pavement is brought about by the load distributing characteristics of each layer in the layered system. The layers of a flexible pavement structure typically consist of hot mix asphalt (HMA) at the surface (wearing course), a binder course (HMA), base course (well-graded gravel), and subbase course gravel, all placed on the sub-grade (natural soil along the highway right-of-way). The integrity of highway pavements can be affected by various factors, ranging from environmental, structural, traffic, construction and maintenance. But the scope of this research would be restricted as much as possible to the structural factors basically the subgrade (geotechnical) contributions.

A highway pavement is a structure consisting of superimposed layers of selected and processed materials above the natural soil or subgrade, whose primary function is to distribute the vehicle applied load to the subgrade [3]. The pavement structure should be able to provide a surface of acceptable riding quality, adequate skid resistance, favourable light characteristics, and low noise pollution. The aim is to ensure that the transmitted stresses due to wheel load are sufficiently reduced, so that they will not exceed the bearing capacity of the subgrade. Two types of pavements are majorly recognized, which are flexible and rigid pavements [4]. The flexible pavement is the main focus of this work. Flexible pavements are the most widely used transportation infrastructures all around the world. The choice of flexible pavements depends on different factors such as the design period, initial cost, traffic, ground conditions (i.e. subgrade layer of the pavement), and environmental factors. Long-term considerations, for example lifetime cost and maintenance budget, are also important factors to be taken into account. The main concept behind design of conventional flexible pavement is to provide layered systems with stiffer materials on the top where the intensity of stress is high and less stiff materials at the bottom where the stress intensity is less. A typical flexible pavement section is composed of asphalt concrete layer, bounded and /or unbounded base layer, sub-base and subgrade layers.
A pavement section can be generally defined as the structural materials placed above a subgrade layer [5]. The structural layers of highway pavements are; the subgrade (support), sub-base, base and surfacing. The characteristic of the soil bed over which the entire pavement system rests represents the subgrade soil. The subgrade provides a foundation for supporting the pavement structure. As a result, the required pavement thickness and the performance obtained from the pavement during its design life would depend largely upon the strength and uniformity of the subgrade. Hence, a thorough investigation of the subgrade should be made so that the design and construction will ensure uniformity of support for the pavement structure and realization of the maximum strength potential from the particular sub-grade soils. Hence, the subgrade soil properties is a key factor that affects pavement structure design. As noted by [6], all pavements derive their ultimate support from the underlying subgrade soils making. Virtually every Civil Engineering structure is built on the ground of which the carriageway pavement is not an exception. However, highway pavements are constructed on the processed subgrade (natural soil) of each section along the roadway. The subgrade can be defined generally as a layer which serves as a foundation in a highway pavement construction. It is a surface of the earth rock levelled off to receive Civil Engineering structures. But the variation of subgrade properties plays undeniable roles in the integrity of highway pavement, so to be able to build a stable and durable pavement, the existing soil strength have to be determined over space as these properties vary over space and over time. Since the subgrade properties along the highway differ, it is important to collect a natural soil sample at many locations along the proposed highway for laboratory tests. The subgrade elastic modulus is paramount to highway pavement design; for granular soils, California Bearing Ratio (CBR) is an indicator which serves as a common way of determining the elastic modulus of subgrade and for cohesive soils (clay) plasticity index is always used.

The objective of pavement design is to provide a structural and economical combination of materials to carry traffic loadings in a given period over the existing soil conditions for a specified time interval of design life. It also functions to receive and transmit traffic loads through the pavement layers to the sub-grade [7]. Highway pavement, just like other Civil Engineering structures, is expected to be durable and resilient; so for it to perform satisfactorily through the design life, characterizing subgrade material is crucial in pavement design, construction, as well as rehabilitation activities.

Pavement integrity is the ability of the pavement structures to uphold adequate serviceability, safety, and good riding quality at least within the design life. Subgrade is the foundation of the pavement infrastructure as it is the layer of pavement that receive loads from the overlaying structures and disseminate it to the earth. So where the foundation of any structure especially in Civil Engineering 
construction is defective, automatically it will affect the look and also the performance of such structure. Some defects that are often observed on the road pavement infrastructure include; rutting, many forms of cracking, potholes, depression, upheaval and so on. These are signs of pavement failure. Reference [8] established some major factors responsible for road failures which include: poor road construction, poor road design, excessive traffic axle load, high water table, wrong choice of construction materials, and collapse of drainage substructures. The transport road research laboratory [9] also argued that climatic factors can also affect the strength of the road structure. Temperature fluctuation and acidic rain attack the base material of the road in waterlogged area, and this likewise aid to weaken the sub base of the road. Also the capillary action of water reduces the supporting power of the road pavement. Some other scholars are of opinion that poor maintenance is the main cause of failure to many road pavements $[10,11]$. The poor geotechnical characteristics of many in-situ soils cannot be overlooked since [12] made it clear that the subgrade soil is an integral part of a road pavement structure, as it provides support to the pavement from beneath; and therefore should possess sufficient strength and stability under adverse climatic and loading condition, so as to avoid failure. This is very important to note as it explained why a road with identical climatic, environmental, traffic loading, maintenance and other stated factors fail at different rates and different severity at various locations along the road. The subgrade properties could vary significantly even at close ranges.

Previous studies have concluded that the condition of the subgrade soil is key to pavement structural performance [13, $14,15]$. It is, therefore, obvious that poor condition of roads such as that of Enugu - Onitsha roadway could be as a result of poor subgrade properties. Variation in subgrade geotechnical properties is a problem not only in recent era; it has always been an issue of main concern as most design methodologies consider it as a key design factor. The inspection of Enugu-Onitsha Expressway shows that many sections of the road pavement have severely failed without reaching the design life, but the fact remains that not all parts of the pavement failed at the same period, despite been plied by the same public service vehicle and other heavy goods vehicles.

Coarse grained soils serve as good subgrades for supporting pavements whereas fine grained soils, particularly clay soils pose problems to Engineering structures like pavements [6]. Pavement failure occurs due to two mechanisms, one is due to the combination of densification and repetitive shear and second is due to the deformation of pavement component layers with more contribution from subgrade, particularly in clayey soils.
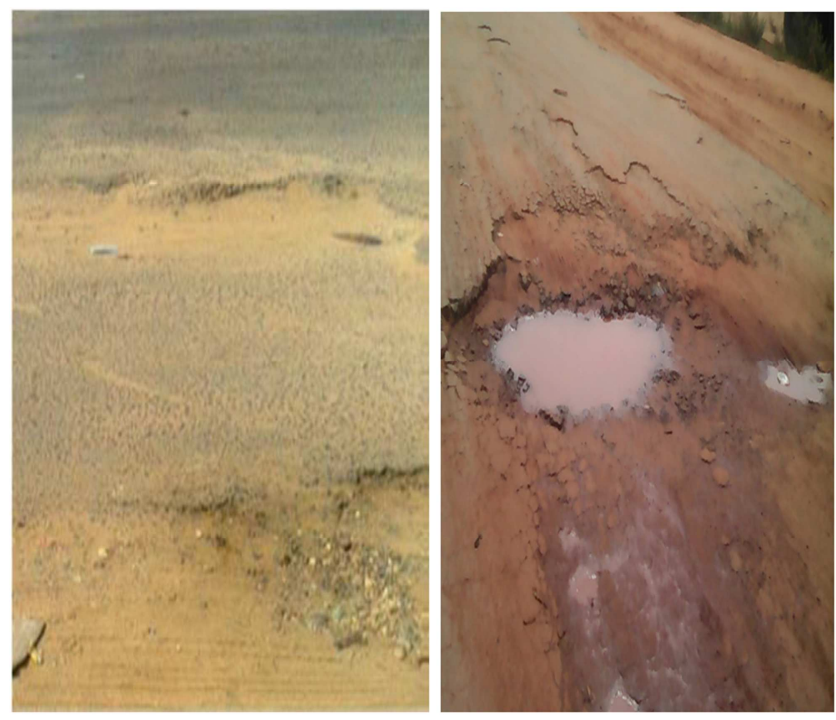

Figure 1. Deteriorated Parts of the Road.

Similarly to a shallow foundation, the soil bearing capacity of the subgrade plays a large role in supporting a road pavement and transferring the vehicle loads. It is necessary to ensure that no shear failure occurs within the subgrade. In the method of plate-load testing, [16] gave a field based test to check soil-bearing capacity (that is ability to carry applied load). The CBR test is a cheaper alternative which is widely employed within Nigeria as an indicator of soil strength. These forms of investigation are necessary because natural soil varies from place to place in texture, structure and many other features. The geotechnical properties of the soil at any point is unique and is expected to perform or react towards imposed loads differently. Reference [17] on the place of soil geotechnical characteristics along the road in the road failure, collected the representative soil samples from both failed and un-failed sections of a road and analysed the samples to ascertain their particle size distribution, liquid limit, plastic limit, maximum dry density, optimum moisture content and California bearing ratio (CBR) values. The data generated from those tests entail that there is significant difference between the geotechnical characteristics of the soil and the standard specification for geotechnical characteristics set by the Federal Ministry of Works at the failed sections but insignificant difference at the un-failed sections of the road. This suggests that the soil geotechnical characteristics is an instrumental factor of the road failure. This is in agreement with the findings of [18] following the same methodology. This research, therefore, aims at analyzing the contribution of the varying subgrade soil strength to the undue, uneven and ununiform failure of the highway pavement. In essence, attempts were made in this study to examine the relation between the subgrade geotechnical data and the design outputs for the pavement thickness. The effects of uncertaintainties as applied to different CBR values of subgrade the pavement performance after construction were explored. 


\section{Research Methodology}

\subsection{Location of Study}

This research work was carried out on the Enugu - Onitsha expressway (a trunk "A" highway), to investigate the effect of the variation in natural soil properties along the roadway. Enugu - Onitsha dual carriageway was first constructed in the late 1970s in Nigeria which is made up of the two carriageway of $7300 \mathrm{~mm}$ width each.

\subsection{Sample Collection}

The soil samples were collected in trial pits of $600 \mathrm{~mm}$ to $1200 \mathrm{~mm}$ depth located very close to the road in question. These representative soil were collected from Nkpor junction (very close to the overhead bridge), Awkuzu junction (about $100 \mathrm{~mm}$ away from the junction along the expressway), and Kwata junction. The soil samples were used in all the laboratory tests.

\subsection{Material Testing}

All tests conducted were in conformity with AASHTO sampling and testing procedures and also as specified by [19] for Roads and Bridges. Specific gravity, sieve analysis, Atterberg limits, compaction, and CBR tests were performed on the samples. Specific gravity is the ratio of the mass of unit volume of soil at a stated temperature to the mass of the same volume of gas-free distilled water at the same temperature. In order to ascertain the percentage of various sizes of soil contained in a particular soil sample, the soil was subjected to sieve analysis. The mechanical or sieve analysis is performed to determine the distribution of the coarser, larger-sized particles, and the hydrometer method is used to determine the distribution of the finer particles. The liquid limit (LL) of a given soil specimen is arbitrarily defined as the water content, in percent, at which a part of soil in a standard Cassagrande cup and cut by a groove of standard dimensions will flow together at the base of the groove for a distance of $13 \mathrm{~mm}$ when subjected to 25 numbers of blows or impact from the cup being dropped $10 \mathrm{~mm}$ in a standard limit apparatus operated at a rate of two drops or impact per second. The liquid limit is the moisture content that defines where the soil changes from a plastic to a viscous fluid state. On the other hand, the plastic limit (PL) is the water content, in percent, at which a soil can no longer be deformed by rolling into $3.18 \mathrm{~mm}$ diameter threads without crumbling. The plastic limit is the moisture content that defines where the soil changes from a semi-solid to a plastic (flexible) state. These Atterberg limits are also used to classify a fine-grained soil according to the Unified Soil Classification system or AASHTO system. Compaction is a mechanical means for the densification of soil. Several methods are used to compact soil in the field, and some examples include tamping, kneading, vibration, and static load compaction, but in the laboratory the tamping or impact compaction methods are employed [20]. The British standard light (BSL) compaction was adopted for this research and the optimum moisture contents established therefrom were used for the CBR tests. Table 1 is the summary of the BSL compactive effort parameters.

Table 1. The Compaction Parameters.

\begin{tabular}{ll}
\hline Compaction & BS Light \\
\hline Number of layers & 3 \\
Number of blows & 27 \\
Rammer weight $(\mathrm{Kg})$ & 2.5 \\
Mould volume $\left(\mathrm{cm}^{3}\right)$ & 1000 \\
Height of fall $(\mathrm{m})$ & 0.45 \\
\hline
\end{tabular}

The CBR is a small scale penetration test defined as the ratio of the force per unit area required to penetrate a soil mass with a circular plunger of $50 \mathrm{~mm}$ diameter at the rate of $1.25 \mathrm{~mm} / \mathrm{min}$ to that required for a corresponding penetration of a standard material. This laboratory test covers the determination of the California bearing ratio of a soil which is obtained by measuring the relation between load and penetration when a cylindrical plunger is made to penetrate the soil at a given rate. At any value of penetration the California Bearing Ratio (C.B.R) values are normally quoted for $2.50 \mathrm{~mm}$ and $5.00 \mathrm{~mm}$ penetration.

\subsection{Traffic Survey}

A four hour road count was made at the same locations where the soil samples were collected (Nkpor, Awkuzu, kwata). The traffic count was done by direct observation and manual counting, the collected data were recorded and analysed using recording sheets. The commercial vehicles counted were classified thus; Buses and Coaches, 2-axle rigid, 3-axle rigid, 4-axle rigid, 3-axle articulated, 4-axle articulated, 5-axle articulated, and 6-axle articulated.

\subsection{Traffic Assessment and Structural Design}

The traffic assessment and structural design was done using the Design Manual for Highways and Bridges [21] methodology. The design Traffic was determined and the thicknesses of the pavement layers were selected accordingly. Equations 1 and 2 below are the models for computing the design traffic. Whereas the parameters like the percentage of commercial vehicles in heaviest traffic lane $(\mathrm{P})$, growth factor $(\mathrm{G})$, and Wear factor (W) were gotten from relevant charts, the traffic flow $(F)$ was gotten from the survey data and design life $(\mathrm{Y})$ was taken as 20 years which is typical for flexible pavements.

$$
\begin{aligned}
& \text { Weighted Annual Traffic }=365 \times F \times G \times W \times 10^{-6} \mathrm{msa} \\
& \text { Design Traffic (T) }=365 \times F \times Y \times G \times W \times P \times 10^{-6} \mathrm{msa}
\end{aligned}
$$

\section{Results and Discussion}

\subsection{Particle Size Distribution}

Comparing the particle size distribution characteristic of the tested samples from figure 2 below, it can be fathomed that almost all the soil samples fall under sand though with 
some unique characteristics. The soil samples from Nkpor area according to the graph contains about $85 \%$ sand and fines of about $15 \%$, this indicates that the soils in that area are mostly sands. Kwata junction region is almost direct reverse of Nkpor soil sample because it contains about $80 \%$ fines and $20 \%$ sand, which entails that the soil is of high clay content. Close to $45 \%$ and $55 \%$ fines and sands respectively were identified to be contained by the soil sample from Awkuzu junction area, showing that the soil contains close amounts of fines and sand.

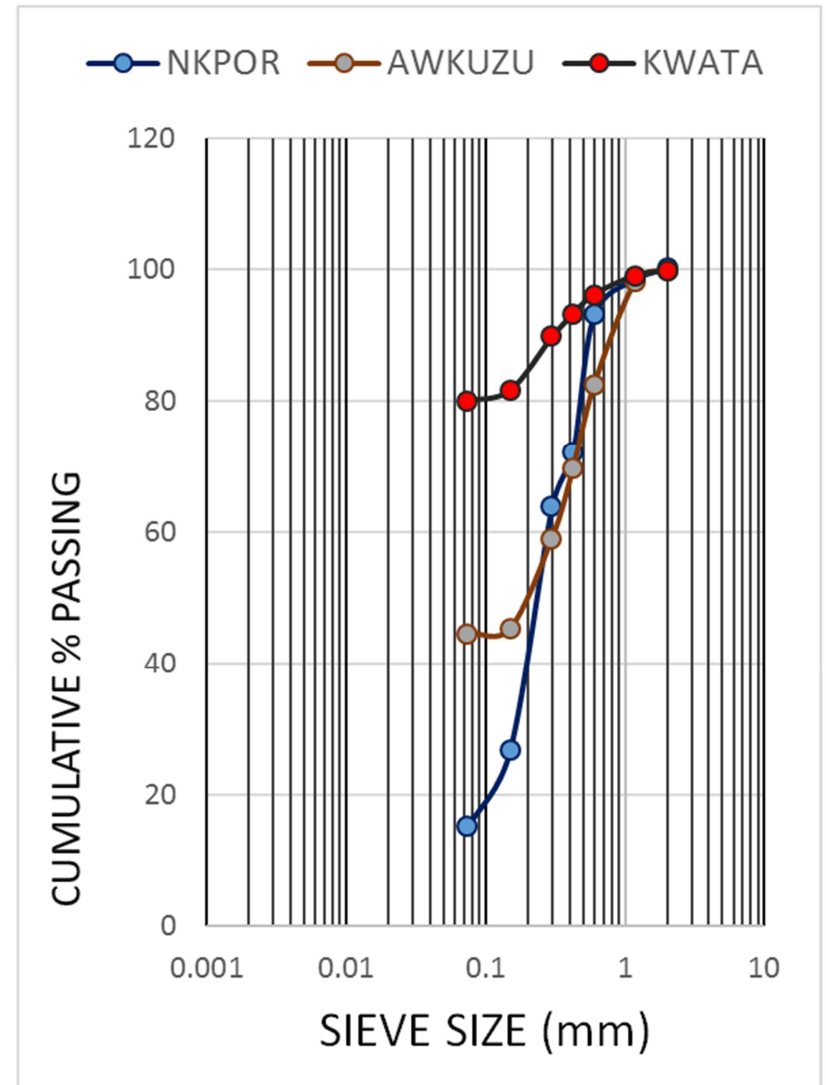

Figure 2. Particle Size Distribution Curves for the Three Soil Samples.
From the skewedness of the curves, the soil sample from Awkuzu, Nkpor, and Kwata are well graded, poorly graded, and well-graded respectively. From the above particle size analysis result, the three soil samples contain quite a high amount of sand that makes them non-plastic. The $\mathrm{D}_{10}$ has no value for both soil samples. The coefficients of uniformity and curvature $(\mathrm{Cu}$ and $\mathrm{Cc})$ were not ascertained hence were not used for the soil classification. In this case, therefore, the American Association of State Highway and Transport Official (AASHTO) soil classification method was used to classify the samples. The Nkpor soil sample was classified as an A-2 (A-2-4) indicating that the sample is non-plastic silty or clayey sand which could be rated as good to fair subgrade/fill materials. From the curve $\mathrm{D}_{30}, \mathrm{D}_{60}$ can be gotten as 0.16 and 0.28 respectively. The sample collected at Awkuzu, with $45 \%$ fines was classified as an A-6 (2) soil which indicates a moderately plastic soil that could perform fairly or even badly as a subgrade material. The Kwata sample contains much higher fines. Therefore the $80 \%$ of fine in Kwata soil sample in comparison with not greater than or equal $35 \%$ stated in code shows that it is bad subgrade material for road constructions. Looking at curve of this sample, the coefficient of uniformity $\left(\mathrm{C}_{\mathrm{u}}\right)$ or curvature $\left(\mathrm{C}_{\mathrm{c}}\right)$ cannot be calculated just like for the other two samples, but in this case even $\mathrm{D}_{30}$ and $\mathrm{D}_{60}$ could not be estimated. So the sample were classified with AASHTO soil classification method as the A-4 (5), showing that it is clayey and silty fines mainly with little sand.

The particle/grain size distribution of a soil is an important determinant of its geotechnical characteristics. In Civil Engineering construction, clay materials are seen as troublesome, though porous but is less permeable and to determine the percentage of clay present in the natural soil (subgrade) in order to know whether it will serve as a good subgrade, particle size distribution determination is inevitable. And the analyses for these three samples already points to subgrade weakness as a major contributor to pavement failure along the Enugu-Onitsha express road. The summary of these results and some other Index properties of the soil samples are presented in the table 2 below.

Table 2. Summary of the Laboratory Tests Results and estimated Index Properties.

\begin{tabular}{|c|c|c|c|c|}
\hline Sample locations & & NKPOR & AWKUZU & KWATA \\
\hline Depth (mm) & & 750 & 1200 & 650 \\
\hline \multirow{2}{*}{ Sieve Analysis } & Fines (passing $75 \mu \mathrm{m}$ ) & 15 & 45 & 80 \\
\hline & Sand $(\%)$ & 85 & 55 & 20 \\
\hline \multirow{3}{*}{ Atterberg Limits } & Liquid Limit (\%) & - & 31 & 27.4 \\
\hline & Plastic Limit (\%) & - & 20 & 18.35 \\
\hline & Plasticity Index & - & 11 & 9 \\
\hline Specific Gravity & & 2.62 & 2.6 & 2.58 \\
\hline \multirow{2}{*}{ Compaction } & OMC (\%) & 11.7 & 11 & 14.6 \\
\hline & $\operatorname{MDD}\left(\mathrm{Kg} / \mathrm{m}^{3}\right)$ & 1852 & 1980 & 1788 \\
\hline \multicolumn{2}{|c|}{ AASHTO Classification } & A-2-4 & A-6 & A-4 \\
\hline \multicolumn{2}{|l|}{ Group Index (GI) } & 0 & 2 & 5 \\
\hline \multicolumn{2}{|c|}{ Usual type of material } & Silty or Clayey sand & Clayey Soil & Silty Soil \\
\hline \multicolumn{2}{|c|}{ Subgrade rating } & Good & Fair to Bad & Fair to Bad \\
\hline
\end{tabular}




\subsection{Consistency Limits}

These limits measure the moisture content at which soils change from one state to the other as water is added or withdrawn from that particular soil sample. It has been found useful in evaluation of subgrade and subbase materials. The results for the three soil samples are presented in table 2 . From the results, it could be said that the soil sample collected at Awkuzu, is plastic in nature with liquid limit of $31 \%$. Since this value do not exceed the standard specified by FMW for roads and bridges (that is LL $\leq$ $80 \%$ and PI $\leq 55 \%$ ), it could be used for subgrade and fill material. The soil sample been classified with AASHTO soil classification method indicates that it is in class of A-6 (2) which accredited as fair to poor subgrade material and the usual material is mostly silty soils. There the value of liquid Limit for the Kwata soil sample is $27.4 \%$. This shows that the soil is plastic in nature with liquid limit (LL) value less than the specification in the standard code of practice maximum specifications ( $\mathrm{LL} \leq 80 \%$ ) for subgrade materials, it therefore suggests that Kwata soil could be used as subgrade materials since it met the required specification. The result computation shows that the plasticity index ranges from $9 \%$ to $11 \%$ which is an indication that the both sample are of medium plasticity and these values do not exceed the standard specification of $\leq 55 \%$. Since the samples met the specification, it then suggest that soil sample could be used as subgrade materials. But these are will remain subject to the CBR values which is a more acceptable performance indicator.

\subsection{Specific Gravity}

The specific gravity values gotten from the tests are within the range of 2.58 to 2.62 showing that it is silt or clay finesand with appreciable amount of silt or clay. The values of the specific gravity of the three samples have been indicated in table 2. They are above the specified minimum for subgrade materials thereby implying that they could be adequate.

\subsection{Compaction}

It was ascertained that the maximum dry density (MDD) and optimum moisture content (OMC) varied between $1788 \mathrm{Kg} / \mathrm{m}^{3}$ and $1980 \mathrm{Kg} / \mathrm{m}^{3}, 11 \%$ and $14.6 \%$ respectively for the three samples. The MDD values are within the range for good subgrade soils. Figure 3 is the compaction curves for the three samples tested.

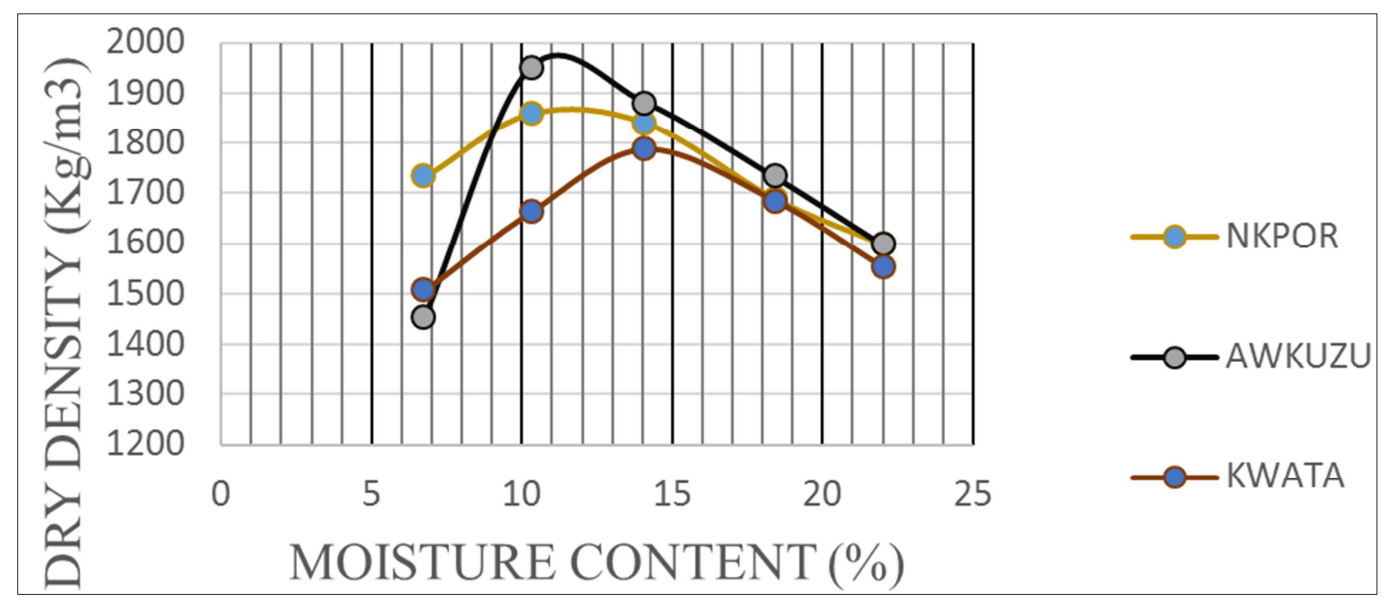

Figure 3. The Compaction Curves for the Three Soil Samples.

As expected, it can be observed from the figure 5 that the higher the Maximum Dry Density (MDD), the lower the Optimum Moisture Content (OMC). Awkuzu soil sample has the highest MDD but lowest OMC, while the sample collected from Kwata which has the highest OMC among the tested samples achieved the lowest MDD at the same compactive effort. Besides, the optimum moisture content range of $3.6 \%$ is quite significant to note.

The variation in the compaction characteristics of the subgrade soils along the length of the expressway is quite significant, indicating that using a particular OMC for the construction at the subgrade level would not achieve a the best compaction for all the sections of the road. The minimum value of MDD for subgrade materials is $1760 \mathrm{~kg} / \mathrm{m}^{3}$ according to the Federal Ministry of Works and Housing (FMWH) specification. And can be seen from table 2 and figure 5, the three soil samples met this requirement but varies from each other.

\subsection{California Bearing Ratio}

The 48 hours soak California Bearing Ratio values were recorded and the results were observed to be $2.3 \%, 8 \%$ and $9 \%$ for Kwata, Nkpor and Awkuzu respectively. Apart from the sample collected at Kwata, the other two samples minimum 5\% CBR specification for subgrades according to FMWH. The higher clay content of the samples might have been responsible for reduction in $\mathrm{CBR}$. Areas with $\mathrm{CBR}$ values as low as the Kwata sample needs material replacement or improvement before pavement construction on them. Figures 4 to 6 are the CBR determination curves and tables. 

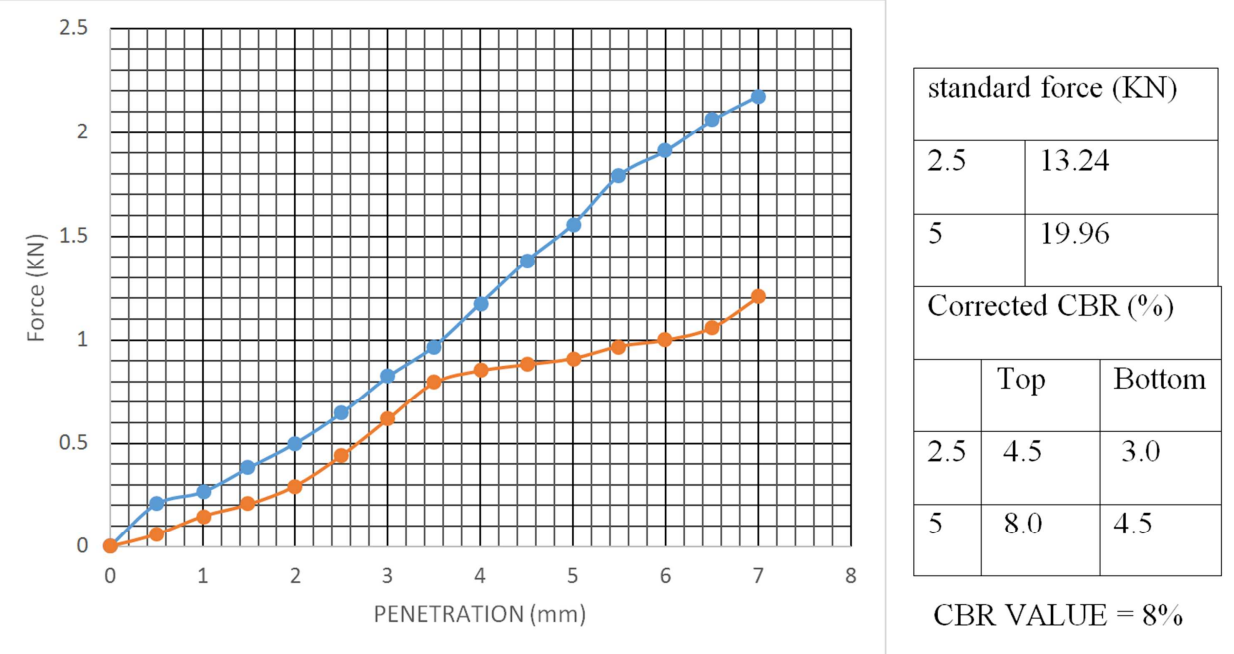

Figure 4. Nkpor Soil Sample CBR Curve.
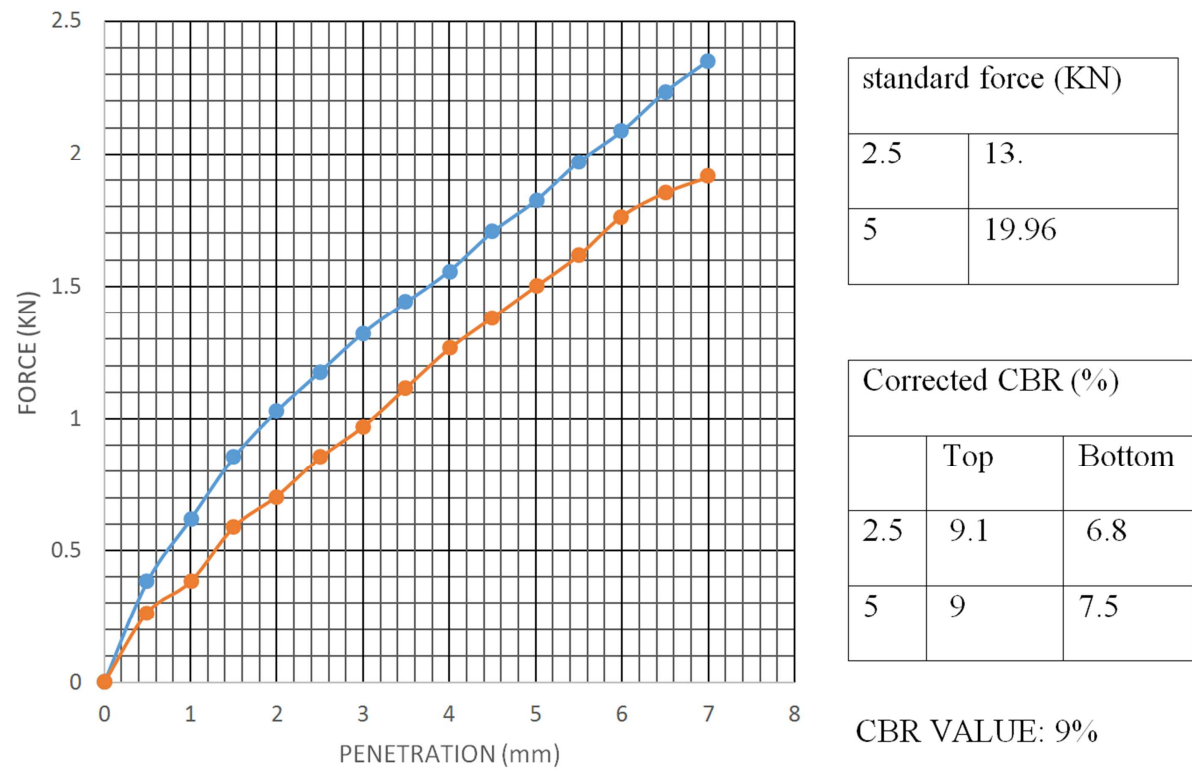

Figure 5. Awkuzu Soil Sample CBR.

\begin{tabular}{|l|l|l|}
\hline \multicolumn{3}{|c|}{ Corrected CBR (\%) } \\
\hline & Top & Bottom \\
\hline 2.5 & 9.1 & 6.8 \\
\hline 5 & 9 & 7.5 \\
\hline
\end{tabular}

CBR VALUE: 9\%
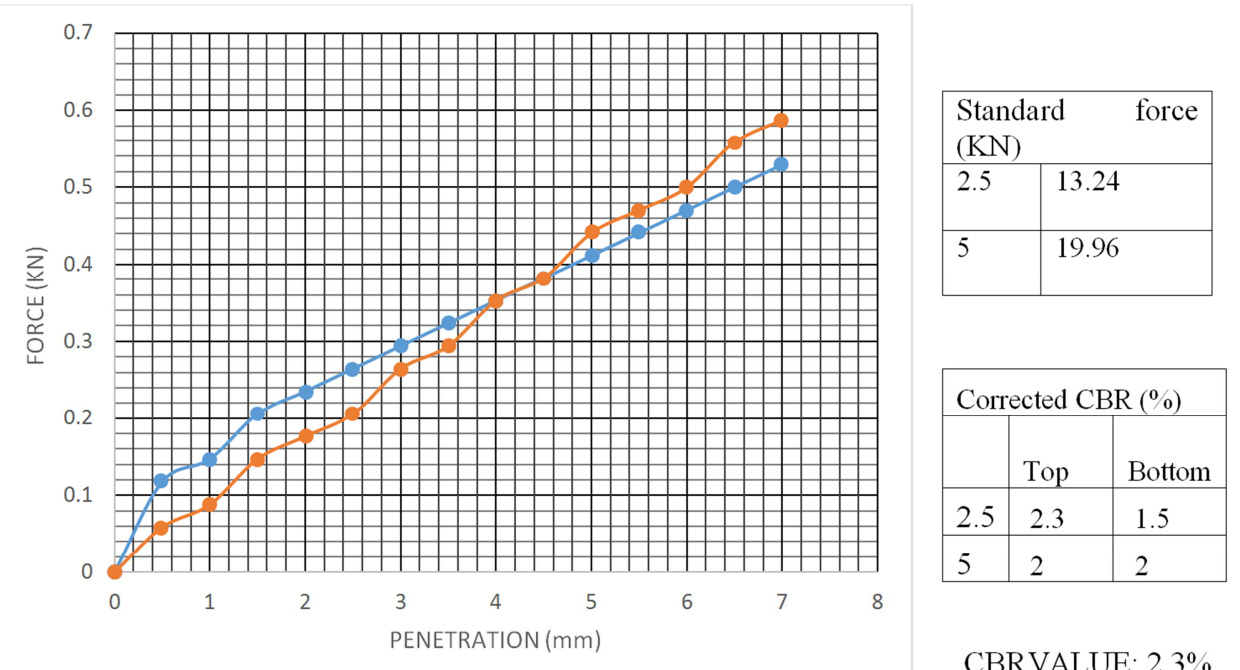

CBRVALUE: $2.3 \%$

Figure 6. Kwata Soil Sample CBR. 


\subsection{Traffic Assessment}

Table 3 below is the summary of the traffic assessment carried out at the three different locations using the HD 24/06 traffic assessment method.

Table 3. Summary of Traffic Data Analysis.

\begin{tabular}{|c|c|c|c|}
\hline Location & NKPOR & AWKUZU & KWATA \\
\hline Total weighted annual traffic $\left(\times 10^{-6}\right)$ & 6.034 & 3.76 & 3.422 \\
\hline Total Daily flow (cv/d) & 6763 & 3909 & 3729 \\
\hline Percentage of vehicle in heaviest traffic lane $(\mathrm{P})$ & $77 \%$ & $85 \%$ & $83 \%$ \\
\hline Design Period (Y) & 20 & 20 & 20 \\
\hline Design Traffic (T) & $92.92 \mathrm{msa}$ & $63.92 \mathrm{msa}$ & $56.81 \mathrm{msa}$ \\
\hline
\end{tabular}

From this summary table, the variation in traffic characteristics at the three locations can be deciphered. Whereas the Awkuzu and Kwata locations could be said to have identical traffic characteristics, the Nkpor Area seems to have much higher traffic volume of commercial vehicles and consequently, a very high design traffic. This suggests that variation in design traffic can also affect the reliability of pavement design. Besides, the major aim of this traffic assessment exercise is to generate the design traffic necessary for the pavement thickness selection.

\subsection{The Thicknesses of Pavement Layers}

Modern pavement design is concerned with developing the most economical combination of pavement layers that will ensure traffic and other climatic loads are transmitted evenly on the subgrade and still sustain its performance adequately at least within the design life. The HD26/06 design code designs pavement with different foundation classes considering the subgrade surface modulus which in turn is a function of subgrade CBR. Figures 7 to 9 illustrates the design outputs for the pavement thicknesses based on foundation classes 3 and 4 as well as different construction materials. The CBR values gotten from the Nkpor and Awkuzu locations were employed for the pavement designs. As expected, lower CBR values requires higher pavement thicknesses. The difference in the output is more pronounced at the base layer which is the major structural layer of a flexible pavement.

\begin{tabular}{|c|c|c|c|}
\hline NKPOR & & AWKUZU & \\
\hline & $50 \mathrm{~mm}$ Surfacing & & $50 \mathrm{~mm}$ Surfacing \\
\hline & HRA50 Binder & & HRA50 Binder \\
\hline & $300 \mathrm{~mm}$ Base & & $280 \mathrm{~mm}$ Base \\
\hline & $150 \mathrm{~mm}$ Subbase & & $150 \mathrm{~mm}$ Subbase \\
\hline 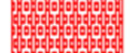 & $180 \mathrm{~mm}$ & & $180 \mathrm{~mm}$ \\
\hline \begin{tabular}{c}
3 \\
\hdashline \\
\hdashline \\
\hdashline
\end{tabular} & Subgrade & & Subgrade \\
\hline & FOUNDATION CLASS 3 DESIGN & & \\
\hline
\end{tabular}

Figure 7. Required Pavement Thicknesses based on Foundation Class 3.

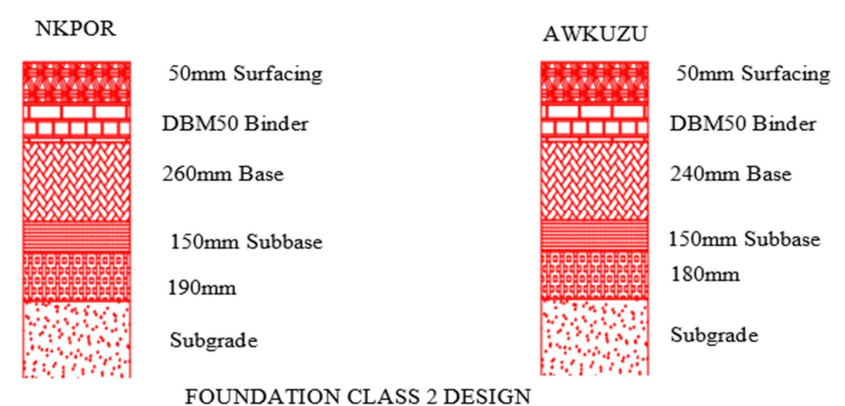

Figure 8. Required Pavement Thicknesses based on Foundation Class 2.

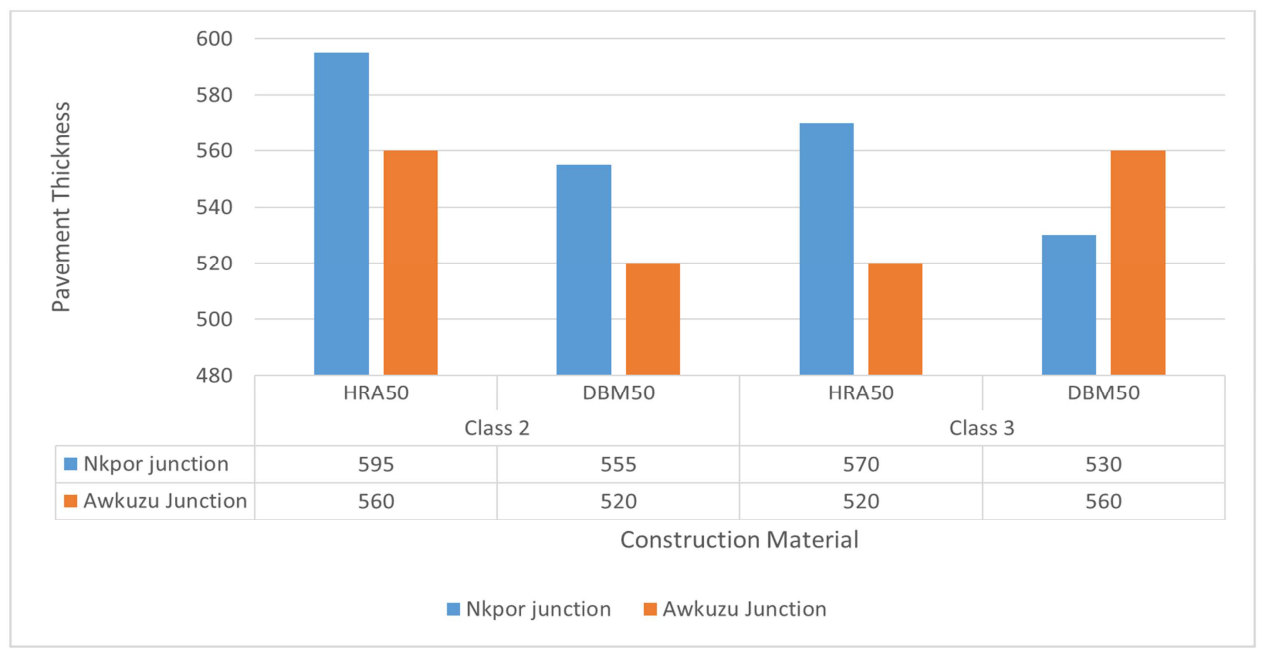

Figure 9. Variation of Total Pavement Thickness with Construction Material. 
Figure 9 shows variations in total pavement thicknesses when different materials are used for the road construction. It shows that HRA50 would give same performance as DBM50 only at a higher thickness. When constructing pavements with either hot rolled asphalt (HRA) or dense bitumen macadam (DBM), one will expect lesser pavement thickness with foundation class 3 design than class 2 .

The practice by most local construction companies has been to design a length of highway with the observed worst CBR value. In other words, the road pavements are designed with the least CBR value gotten along the road in question. In the stations examined along Enugu-Onitsha expressway, the least CBR value is $2.3 \%$. It could be possible for contractors to have taken samples at locations with higher CBR values, and designing with such values is wrong as the actual worst condition has not been considered. It is therefore necessary to dissuade such practice of designing a long length of road with the observed worst CBR. This will be uneconomical for areas with significantly higher surface modulus as well as providing insufficient thicknesses for areas with lower actual CBR than the observed.

\subsection{Relationship Between Subgrade CBR and Pavement Total Thickness}

Hypothetical designs were made varying subgrade CBR values within the range of values encountered in this study. A simple linear regression model was fitted to test the linear relationship between subgrade CBR and pavement thickness and the output is presented as figure 10 and table 4 . The negative slope of the curve entails that road pavement thicknesses increases with decrease in the subgrade CBR values, which is as expected. The p-values for the intercept and subgrade coefficient are far less than $5 \%$ and the Rsquare value is $98 \%$ showing a very strong correlation between pavement thickness and subgrade CBR. The negative sign of the subgrade $\mathrm{CBR}$ coefficient reveals that this correlation is negative. It could be therefore, inferred that there is an overwhelming statistical evidence to conclude that there is a negative linear relationship between pavement thickness and the subgrade CBR.

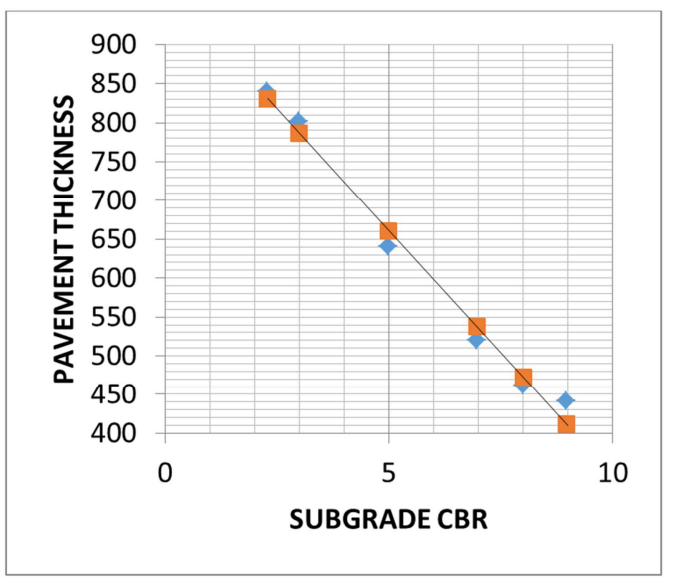

Figure 10. The Line Fit Plot (Pavement Thickness vs Subgrade CBR).
Table 4. Summary of Test Statistics and Analysis of Variance.

\begin{tabular}{lllll}
\hline & Coeffi-cients & Stand. Error & t Stat & P-value \\
\hline Intercept & 976.1 & 22.94 & 42.54 & $1.82 \mathrm{E}-06$ \\
SUBGRADE CBR & -62.88 & 3.6791 & -17.09 & $6.87 \mathrm{E}-05$ \\
\hline
\end{tabular}

$\mathrm{F}=292.09$, Sig. $\mathrm{F}=0.0000687, \mathrm{R}$ Square $=0.98$

The model can be stated mathematically as;

$[$ Pavement thickness $=976.1-62.88 \mathrm{CBR}]$.

Hence, given any subgrade CBR at any road section, the thickness of the entire pavement cross-section can be predicted using the equation above. This is only necessary to conclude on the subject matter, it does not dismiss the need for proper design, besides the model does not cover the proportioning of the thicknesses to various layers.

\section{Conclusion}

This research work was carried out to investigate the effect of variation in subgrade properties on the integrity of flexible pavement design using Enugu-Onitsha expressway as a case study. The geotechnical properties of the analysed samples shows variation along the highway, the soil sample collected from Nkpor area has about $85 \%$ of fine sand, Awkuzu soil sample contains fine sand up to $55 \%$ and Kwata has about $20 \%$ fine sand. The specific gravity varied from 2.58, 2.60, and 2.62 on the sample collected from Kwata, Awkuzu and Nkpor stations respectively. The specific gravity of the soils are high and this portray resistant soil material which can withstand surface erosion even when water infiltrate into it through the pavement. The OMC and MDD differs at each station, Nkpor has OMC and MDD of $11.7 \%$ and $1852 \mathrm{Kg} / \mathrm{m}^{3}$ while Awkuzu and Kwata OMC and MDD are $11 \%, 1980 \mathrm{Kg} / \mathrm{m}^{3}$ and $14.6 \%$, $1788 \mathrm{Kg} / \mathrm{m}^{3}$ respectively. The results indicate that the increase in the $\mathrm{OMC}$ reduces $\mathrm{MDD}$, therefore, it was confirmed that the moisture content of any given soil sample affects the soil strength.

The California Bearing Ratio (CBR) of the three tested soil samples collected from Nkpor, Awkuzu, and Kwata area $8 \%, 9 \%$, and $2.3 \%$ respectively, showing that there is significant variation in the CBR value of the soil along the road pavements. Suggesting that there might be some locations of higher CBR value greater than $9 \%$ or lower than $2.3 \%$. The road pavement thicknesses were determined from the subgrade CBR and design traffic values for each station, it shows that higher in CBR values would require lesser pavement thicknesses. Areas with CBR values as low as $2.3 \%$ requires an overall pavement thickness of up to $840 \mathrm{~mm}$ which is very high, a subgrade with such low CBR cannot be designed with HD26/06. Selecting the road pavement thicknesses using the observed worst condition (lowest CBR value) scenario shows a very high thickness of $840 \mathrm{~mm}$ in the sections of the road since single CBR value would be utilized for all sections of the expressway and that there will a waste in materials in some sections, this suggests a great economic loss. Therefore, designing a 
length of highway with a single CBR value will be uneconomical for areas with significantly higher surface modulus as well as providing insufficient thicknesses for areas with lower actual CBR than the observed. Sectional pavement design at not more than $1 \mathrm{~km}$ intervals is recommended.

\section{References}

[1] L. Qiang, M. Leslie, and M. Sue. "The Implication of Climate Change on Pavement Performance and Design". A Report Submitted to the University of Delaware Transportation Centre (UD-UTC) 2011.

[2] Florida Department of Transport. "Flexible Pavement Design Manual" 2008. [Online] Assesed from http://www.dot.fl.us/pavementmanagement.com/ Assessed on $3^{\text {rd }}$ March 2016.

[3] C. A. O'Flaherty. "Highways: The Location, Design, Construction, and Maintenance of Pavements". Butterworths and Heinemann, Oxford United Kingdom (2012).

[4] M. Rogers. "Highway Engineering". Second Edition, Blackwell Publishing, Oxford, UK (2012).

[5] J. W. Adrox and W. R. Woods. "A General Characterization of Pavement System Failures with Emphasis on a Method for Selecting Repair Process". Journal of Construction Education, 7 (1), (2002) pp 58-62.

[6] E. J. Yoder and M. W. Witzack. "Principle of Pavement" $\left(2^{\text {nd }}\right.$ ed.), John Wiley \& Sons, New York (1975).

[7] L. R. Kadiyali. "Highway Engineering" $3^{\text {rd }}$ edition. CBS Publishers and Distributors Pvt Ltd. New Delhi, India (1989).

[8] S. W. Abynayaka. "Prediction of Road Construction Failure in Developing Countries". Proceedings. Institute of Civil Engineering Vol. 62 (3) Part I, ICE Virtual Library (1997), Pp 419-446.

[9] Transport Road Research Laboratory (TRRL). "Maintenance Techniques for District Engineers", Vol. 2, (1991) TRRL. Crow Thorne England.

[10] T. Igomu. "Year Major Highways Collapsed into Death
Traps”. Daily sun newspaper Thursday $29^{\text {th }}$ December 2011, page 34 .

[11] H. N. Paul, and J. P. Radnor. "Highway Engineering”, John Willey and Sons, New York (1976).

[12] B. L. Gupta, and A. Gupta. "Highway and Bridge Engineering", Standard Publishers Distributors, Delhi, India (2008).

[13] O. A. Adeleke, and A. O. Madebor. "Effect of Hydrated Lime on the Atterberg Limits of Black Cotton Soil of Nigeria". 9th Regional Conference for Africa on Soil Mechanics and Foundation Engineering, 1, (1987). pp 155-160.

[14] O. M. Ogundipe. "Road pavement failure caused by poor soil properties along Aramoko-Ileha Highway Nigeria". Medwell journal of Engineering and Applied Science. Vol. 3 (3), (2006) pp 239-241.

[15] G. Jegede. "Highway Pavement Failure Induced by Poor Geotechnical Properties along a Section of F209 OkitipupaIgbokoda Highway". Nigeria Ife Journal Science, 6 (1), (2004). pp 41-44.

[16] B. M. Das. "Principles of Geotechnical Engineering", 6th edition, Thomson, Brooks/Cole 97, (2006).

[17] D. C. Onuoha, and S. U. Onwuka. "The Place of Soil Geotechnical Characteristics in Road Failure, a Study of the Onitsha-Enugu Expressway, Southeastern Nigeria". Civil and Environmental Research. Vol. 6 (1), (2014) pp 55-66.

[18] G. O. Adeyemi, M. O. Oloruntola, and A. O. Adeleye. "Geotechnical Properties of Subgrade Soil along Sections of the Ibadan-Ife Expressway, South-Western Nigeria"; Journal for Natural Science Research. Vol. 4 (23) (2014) pp 55-67.

[19] Federal Ministry of Works and Housing (FMWH). "General Specification for Roads and Bridges" Revised Edition Vol. 2. : Federal Ministry of Works, Abuja (1997).

[20] C. M. Nwakaire, C. M. O. Nwaiwu, and C. H. Aginam. "Equivalent Blows Approach to the Calibration of a Minicompactor for Laboratory Use". IISTE Journal of Civil and Environmental Research. Vol 7, Issue 8. (2015) pp 63-74.

[21] Traffic Assessment, HD/06, "Design Manual for Roads and Bridges", Vol. 7, Section 2. London: The Department of Transport, February 1996. 